\title{
P-p68 Inhibitor RX-5902
}

National Cancer Institute

\section{Source}

National Cancer Institute. P-p68 Inhibitor RX-5902. NCI Thesaurus. Code C113293.

An orally bioavailable small molecule inhibitor of phosphorylated-p68 RNA helicase (Pp68), with potential anti-proliferative and antineoplastic activity. Upon oral administration, P-p68 inhibitor RX-5902 may both inhibit the activity of the anti-apoptotic B-cell lymphoma 2 ( $\mathrm{Bcl}-2)$ protein and facilitate the induction of cyclin-dependent kinase inhibitor 1 (p21). This may prevent G2/M cell cycle progression and lead to growth inhibition in tumor cells. P-p68 is overexpressed in various types of solid tumors but absent in normal tissues, and plays a role in tumor progression and metastasis. p21 is a potent cyclin-dependent kinase inhibitor which regulates cell cycle progression and mediates both growth arrest and cellular senescence. 